\title{
Кирдеева А.М. \\ Семантика и функционирование глаголов восприятия в современных англоязычных художественных текстах
}

Балтийский Федеральный университет имени И.Канта (Россия, Калининград)

doi: $10.18411 / \mathrm{sr}-10-08-2017-16$

idsp: 000001:sr-10-08-2017-16

\section{Аннотация:}

Статья посвящена особенностям функционирования глаголов восприятия в англоязычных художественных текстах, рассматриваются примеры многозначности некоторых глаголов

Ключевые слова: Семантика глаголов восприятия, многозначность, функционирование глаголов, каналы восприятия, базовые глаголы.

Тема восприятия в настоящее время широко исследуется многими лингвистами. За последнее время тема стала актуальной для многих исследователей - лингвистов (Дмитриева Е.Г, Козюра Т.Н. Кузнецова С.С. Сафонова А.А, Чумакова Г.В,). Восприятие как процесс, вызывает интерес исследователей в психолингвистике, нейролингвистике, а также у зарубежных исследователей. Глаголы восприятия передают отражение современной картины мира. Существует немало статей посвященных особенностям употребления глаголов восприятия (Фатхутдинова В.Г, Петрова И.П. ,Слепцова Л.А, и.т.д.) Согласно когнитивной лингвистике, человек воспринимает информацию, а затем он посредством своих внутренних состояний передает данную информацию тем, самым образую свою картину мира. «Прибегая к метафоре, можно назвать глаголы восприятия «воротами» из мира объективной реальности в мир языковой, они обозначают первый производный и непроизводный контакт человека с объективным миром.»[5;73]

Лексикография всегда ставила вопрос перед теоретической семантикой о создании исчерпывающих значения слов. Основными элементами языка является, слово и его лексическое значение, в нем отражается веками, хранится социально исторический опыт носителей данного языка. «Передача лексических значений осуществляется на коммуникативном уровне, именно на этом уровне оно представлено наиболее полно, многообразно, во всех его разновидностях и комплексном взаимодействии.»[5;26]

«Известно что теоретическая семантика предшествующей эпохи занималась почти исключительно вопросом о том, как слова значат. Именно этому посвящено учение о способах развития значений - сужении и расширении, дифференциации и аттракции, метафоре и метонимии и т. п., а также более тонкие наблюдения над направлением переносов - от пространственных значений - к временным, но не наоборот, от потіna anatomica - к именам физических предметов, но не наоборот; от названий свойств, воспринимаемых осязанием, обонянием и вкусом, - к названиям свойств, воспринимаемых зрением или слухом, но не наоборот; и ряд других.» $[1 ; 6]$

Глаголы восприятия представляют собой традиционно пять сенсорных систем человека, зрение, слух, обоняние, осязание и вкус. В английском языке каждая группа глаголов, как и в других языках, образует свое микрополе глаголов сенсорных систем. Среди данных глаголов есть наиболее часто употребляемые глаголы, частотность употребления данных глаголов очень высока, это так называемые ядерные глаголы. Они свободно могут употребляться в других значениях, также у них отсутствуют стилистические ограничения в употреблении. Итак, наиболее часто употребляемыми глаголами восприятия в английском языке являются глаголы:

1) Зрительный канал- Look, see, glance, recognize, notice

2) Слуховой канал- hear, listen 
3) Обонятельный канал- smell, feel

4) Вкусовой канал- taste, feel, try

5) Канал осязания- feel, sense, push

Надо отметить, что такой глагол как "feel" может употребляться в разных коннотациях и свободно функционировать в разных каналах, например:

"The car was overheated and smelled of stale takeaways. I began to feel nauseous." [12;32]

В данном примере мы видим что глагол “feel" имеет коннотацию вкусового восприятия, в то время как второй пример выражает осязание кожей, в его прямом значении:

"When I got beneath the shower, the water felt like a hail of sharp gravel being hurled at my tender skin".[11;41]

Глагол “feel" может означать речемыслительную деятельность, например:

"But I felt I had no right to mind about the girl and that I didn't make any difference anyway." [11;39]

или выражать эмотивность:

"Late in the day we dotted the final "I" and crossed the final " $\mathrm{t"}$, and even though I was wrecked I felt light and happy." [11;6]

Однако, он не перестает быть глаголом восприятия, хотя как видно из примеров многозначен.

Глаголы зрительного восприятия составляют примерно 80 процентов от всех глаголов восприятия, это связано с тем, что зрение является одной из ведущих каналов взаимодействия с внешним миром. Зрительная система намного сложнее. Она больше, в ней участвует почти треть мозга. И хотя электрические сигналы в мозге распространяются с одной скоростью, зрительные сигналы обрабатываются сложнее и на это теряется время.

Изучая современные художественные англоязычные тексты, глаголы зрительного восприятия встречаются намного чаще остальных глаголов.

\section{Например:}

"The doctor stared at her for a moment, then blinked, glanced down and shuffled his papers. Clearing his throat, he said, 'Don't mention it. I can see that you are a nice family, who've hit a bad patch in your lives'. He looked up again and smiled, once more in control of himself. 'I hope you're right and that your father returns for you very soon. 'He glanced towards Sarah. 'Perhaps by then he'll have become a father again. In the meantime, we'll take good care of you all'.[10;65]

Из приведенных примеров можно сделать вывод что, глаголы восприятия многозначны и передают некоторые смысловые особенности других лексических единиц.

$$
\text { *** }
$$

1. Апресян Ю.Д.- « Лексическая семантика»Изд. «Восточная литература» PAН, 1995.-VIII с., 472 c.

2. Дмитриева Е.Г, Сафонова И.А, -« Глаголы восприятия и эмоций в древнерусском языке vs тексте: функционально- семантическая характеристика», Вестник Волгоградского государственного университета. Сер. 2, Языкозн. 2015. № 4 (28)

3. Козюра Т.Н.- «Залоговые значения глаголов зрительного восприятия (на материале русского и французского языков», Вестник ВГУ, серия: Лингвистика и межкультурная коммуникация, 2007, № 2 , Ч. 1

4. Кузнецова С.С.- «Базовые глаголы восприятия в речи диалектной языковой личности», Вестник Томского государственного университета. 2014. № 385. С. 16-23

5. Моисеева С.А. «Семантическое поле глаголов восприятия в западно - романских языках», монография, белгород,2005

6. Петрова И.П. « Категоризация мира соматическими фразовыми глаголами лексико- семантической группы восприятия», Вестник ИГЛУ,2012 
7. Слепцова Л.А «Синонимия глаголов со значением «восприятие» как отражение языковой картины мира (на материала синонимических словарей русского и английского языков» Известия Российского государственного педагогического университета им. А.И. Герцена,№60, 2008

8. Фатхутдинова В.Г.- «Деривационная динамика слухового восприятия» Вестник Нижегородского университета им. Н.И. Лобачевского, 2010, № 4 (2), с. 759-762

9. Чумакова Г.В. «О некоторых сложностях восприятия видовременных форм русского глагола в англоязычной аудитории», Вестник ТГГПУ. 2009. №1(16)

10. Margaret Dickinson- "Without sin”,London, Pan books,2005,436p

11. Marian Keyes - “Angels", London,Penguin books,2002,482 p.

12. Robert Harris “The Ghost”,London, Arrow books,2008,400p 